\title{
ANALISA PENGUKURAN BEBAN MODAL RISIKO OPERASIONAL METODE BASIC INDICATOR APPROACH (BIA) DAN ADVANCE MEASUREMENT APPROACH (AMA) DI BANK EFG
}

\author{
Edian Fahmy \\ Program Sudi Menejemen, Fakultas Ekonomi, Universitas Pamulang, Tangerang Selatan, Banten. \\ Email Corespondent : dosen01179@unpam.ac.id
}

\section{Abstract:}

This study aims to compare the magnitude of operational risk losses between the Basic Indicator Approach (BIA) method, and the loss distribution model in the Advanced Measurement Approach (AMA) approach so as to provide a more realistic picture for banks to determine the operational risk capital burden that must be provided based on the causes Operational risks are as follows Internal Process, Human and External Events. Measurement of operational risk capital burden by the AMA method is the determination of frequency of loss distribution, determination of severity of loss distribution, testing with goodness of fit test, then compilation of aggregated loss distribution, calculation of Operational Value at Risk (OpVar), testing the model with back testing and comparison of capital adequacy from the results of the calculation of the Basic Indicator Approach (BIA) and the Advance Measurement Approach (AMA). The results of research based on the BIA require an operational risk capital cost of Rp.291,652,000,000. The results of the research on the AMA approach use the frequency of loss distribution parameter for the internal causes of the process with a Geometric distribution of 0.17561, while for the human cause of 0.08511, for the cause of external events amounting to 0.83721. Determination of Frequency of Loss Distribution using Goodness of Fit for internal processes, people and external events. The results of the Operational Value at Risk (OpVar) with a geometric distribution pattern, then the maximum loss that can arise due to human factors is Rp.24,114,480,096, -, for internal process factors of Rp.6,010,929,367, whereas for external causes for Rp. 2,161,092,909. In total operational risk capital needs through the AMA method of Rp. 32,286,502,372.

Keywords :Risiko operasional, capital charge, Basic Indicator Approach, Advanced Measurement Approacch

\begin{abstract}
Abstrak: Penelitian ini bertujuan Melakukan perbandingan besarnya kerugian risiko operasional antara metode Basic Indicator Approach (BIA), dengan model loss distribution pada pendekatan Advanced Measurement Approach (AMA) sehingga dapat memberikan gambaran yang lebih realistis bagi bank untuk menentukan beban modal risiko operasional yang harus disediakan berdasarkan penyebab risiko operasional sebagai berikut Internal Proses, Manusia dan Kejadian external. Pengukuran beban modal risiko operasional dengan metode AMA berdsarkan penetapan frequency of loss distribution, penetapan severity of loss distribution, pengujian dengan goodness of fit test, kemudian penyusunan aggregated loss distribution, perhitungan Operational Value at Risk (OpVar), pengujian model dengan uji back testing dan perbandingan kecukupan modal dari hasil perhitungan Basic Indicator Approach (BIA) dan Advance Measurement Approach (AMA). Hasil penelitian berdasarkan BIA dengan membutuhkan biaya modal risiko operasional sebesar Rp.291.652.000.000,-. Sedangkan hasil penelitian pada pendekatan AMA menggunakan parameter frequency of loss distribution untuk penyebab internal proses dengan distribusi Geometric sebesar 0.17561, sedangkan untuk penyebab manusia sebesar 0.08511, untuk penyebab kejadian external sebesar 0.83721. Hasil Nilai Operational Value at Risk (OpVar) pada pendekatan AMA dengan pola distribusi geometric, maka kerugian maksimal yang dapat timbul karena faktor penyebab manusia sebesar Rp.24,114,480,096,-untuk faktor penyebab proses internal sebesar Rp.6,010,929,367, sedangkan untuk faktor penyebab kejadian eksternal untuk Rp. 2,161,092,909,--. Secara total kebutuhan modal risiko operasional melalui metode AMA sebesar Rp. 32,286,502,372,-
\end{abstract}

Keywords : Risiko operasional, beban modal, pendekatan indicator dasar, Advanced Measurement Approacch 


\section{PENDAHULUAN}

Pengelolaan risiko semakin disadari sebagai salah satu faktor kunci kesuksesan (key success factor) dari kelangsungan usaha perbankan menghadapi tantangan bisnis perbankan, dalam hal ini termasuk bank umum syariah. Hal ini sejalan dengan meningkatnya tantangan usaha yang dipicu antara lain proses globalisasi yang meningkatkan saling ketergantungan antara sektor keuangan suatu negara dengan negara lainnya, ketatnya persaingan usaha, kemajuan teknologi informasi yang mendorong semakin variatif dan kompleksnya produk keuangan perbankan, dan semakin beragamnya lembaga keuangan.

Berdasarkan Peraturan Bank Indonesia Nomor 13/23/PBI/2011 Tentang penerapan manajemen risiko bagi bank umum syariah dan unit usaha syariah, terdapat 10 jenis risiko untuk bank syariah yaitu risiko kredit, risiko pasar, risiko likuiditas, risiko operasional, risiko kepatuhan, risiko stratejik, risiko hukum, risiko reputasi, risiko imbal hasil (rate of return risk) dan risiko investasi (Equity investment risk). The Basel Committee on Banking Supervision (BCBS), sebuah lembaga yang mengatur perbankan internasional menerbitkan metodologi standar untuk menghitung besarnya risk based capitalyang harus dimiliki bank. Pada tahun 1999 BCBS mengembangkan sebuah ketentuan terkait modal bank (Capital Accord) yang tujuannya merangkum semua risiko bank dalam sebuah kerangka kecukupan modal secara menyeluruh (comprehensive capital adequacy framework), yang kemudian disebut dengan Basel II. Basel II pada bulan Juni 2004, menerbitkan dokumen yang berjudul International Convergence of Capital Measurement and Capital Standards(A Revised Framework), mencantumkan jenis risiko utama perbankan terkait dengan pengukuran kecukupan modal yakni risiko kredit, risiko pasar dan risiko operasional.Dibandingkan dengan risiko kredit dan risiko pasar, perhatian terhadap pentingnya risiko operasional di kalangan perbankan baru dirasakan penting semenjak adanya Basel II.Risiko operasional semakin dianggap penting seiring dengan perkembangan teknologi di dunia perbankan yang mengakibatkan transaksi operasional perbankan dapat berlangsung selama 24 jam diseluruh belahan dunia dengan tersedianya berbagai macam media transaksi electronic banking. Hal lain yang mendukung meningkatnya risiko operasional perbankan adalah munculnya produk produk baru yang perlu mitigasi tambahan yang memadai. Mengacu pada konsep perhitungan rasio modal sesuai Basel II bahwa setiap bank yang belum memiliki model kuantifikasi risiko operasional secara internal (internal model), akan dibebani capital charge berdasarkan metode Basic Indicator Approach yaitu sebesar $15 \%$ dari gross income. Untuk itu setiap bank yangdidorong oleh otoritas atau pengawas perbankan untuk mencari pendekatan internal.Salah satu pendekatan internal yang dipakai dalam karya akhir ini adalah melalui pendekatan Advanced MeasurementApproach (AMA) yang membutuhkan data historis (Loss Event Database). Didalam Surat Edaran Bank Indonesia (SEBI)Nomor7/53/DPbS tanggal 22 November 2005 tentang Kewajiban Penyediaan Modal Minimum bagi Bank Umum Yang Melaksanakan Kegiatan Usaha Berdasarkan PrinsipSyariah, untuk perhitungan kecukupan modal minimum, bank syariah hanya memperhitungkan potensi kerugian atau aktiva tertimbang menurut risiko (ATMR) dari risiko kredit dan risiko pasar belum memperhitungkan potensi kerugian risiko operasional. Perhitungan Kecukupan Pemenuhan Modal Minimum (KPMM) bank syariah "EFG" saat ini belum memasukan potensi kerugian risiko atau aktiva tertimbang menurut risiko operasional. Perhitungan aktiva tertimbang menurut risiko (ATMR) risiko operasional bank syariah "EFG", dilakukan secara terpisah dengan menggunakan metode Basic Indicator Approach (BIA) dengan laba kotor (Gross Income) sebagai proxy untuk eksposur risiko operasional. Seperti diketahui jika laba kotor dijadikan patokan untuk pengukuran eksposur risiko operasional, maka tentunya ini akan sangat berpengaruh pada kecukupan pemenuhan modal minimum karena nilainya sangat besar jika dibandingkan dengan perhitungan eksposur risiko operasional berdasarkan pendekatan Advanced Measurement Approach (AMA).

\section{TINJAUAN PUSTAKA}

\section{Perbankan dan Risiko}

Pengelolaan kelembagaan bank merupakan salah satu faktor penting dalam mewujudkan terciptanya industri perbankan yang sehat, kuat dan dipercaya masyarakat. Bank merupakan lembaga keuangan yang memiliki izin untuk menghimpun dana secara langsung dari masyarakat dalam bentuk simpanan, yaitu berupa giro, tabungan dan deposito. Kemudian dana masyarakat tersebut dialokasikan dalam bentuk pemberian pinjaman kepada masyarakat yang membutuhkan dana, aktifitas ini menjadikan bank sebagai Lembaga intermediary. Dalam proses pengumpulan dan penyaluran dana tersebut muncul berbagai risiko yang dhadapi bank, salah satunya adalah risiko operasional. 
Risiko dalam konteks perbankan merupakan suatu kejadian potensial, baik yang dapat diperkirakan (anticipated) maupun yang tidak diperkirakan(unanticipated) yang berdampak negatif terhadap pendapatan dan permodalan Bank. Untuk dapat menerapkan proses manajemen risiko, maka pada tahap awal Bank harus secara tepat mengidentifikasi risiko dengan cara mengenal dan memahami seluruh risiko yang sudah ada (inherent risks) maupun yang mungkin timbul dari suatu bisnis baru Bank, termasuk risiko yang bersumber dari perusahaan terkait dan afiliasi lainnya.

\section{Manajemen Risiko}

Manajemen risiko menurut Idroes (2008) didefinisikan sebagai suatu metode logis dan sistematik dalam identifikasi, kuantifikasi, menentukan sikap, menetapkan solusi, serta melakukan monitor dan pelaporan risiko yang berlangsung pada setiap aktivitas atau proses.Sedangkan menurut Bank Indonesia manajemen risiko adalah serangkaian metodologi dan prosedur yang digunakan untuk mengidentifikasi, mengukur, memantau, dan mengendalikan risiko yang timbul dari seluruh kegiatan usaha Bank (Peraturan Bank Indonesia Nomor13/23/PBI/2011).Risiko dalam konteks perbankan merupakan suatu kejadian potensial, baikyang dapat diperkirakan (anticipated) maupun yang tidak diperkirakan (unanticipated) yang berdampak negatif terhadap pendapatan dan permodalan Bank.Sehingga risiko bank harus dikelola dengan tepat sehingga dampak negatif yang muncul dapat diminimalisir.Bessis (2001), Banking risks are defined as adverse impacts on profitability of several distinct sources of uncertainty.Sangatlah tepat jika penerapan manajemen risiko harus disusun secara terstruktur, adapun penerapan manajemen risiko diawali tahap identifikasi risiko yaitu dengan cara mengenal dan memahami seluruh risiko yang sudah ada (inherent risks) maupun yang mungkin timbul dari suatu bisnis baru dan aktivitas baru dari Bank. Setelah dilakukan identifikasi risiko secara akurat, selanjutnya dilakukan pengukuran risiko menggunakan metodologi yang ditetapkan, selanjutnya dilakukan pemantauan dan pengendalian risiko. Tujuan dari pengukuran risikodimaksudkan agar bank mampu mengkalkulasi eksposur risiko yang melekat pada kegiatan usahanya sehingga Bank dapat memperkirakan dampaknya terhadap permodalan yang seharusnya dipelihara dalam rangka mendukung kegiatan usaha dimaksud.Sementara itu, dalam rangka melaksanakan pemantauan risiko, bank harus melakukan evaluasi terhadap eksposur risiko, terutama yang bersifat material dan atau yang berdampak pada permodalan Bank.

\section{Risiko Operasional}

Risiko operasional menurut dokumen Basel Committee on Banking Supervision(BCBS, 2004), risiko operasional adalah risiko kerugian yang disebabkan dari kegagalan atau tidak memadainya proses internal, manusia dan sistem, atau kejadiankejadian eksternal. Risiko operasional merupakan risiko yang mempengaruhi semua kegiatan usaha karena merupakan suatu hal yang inherent dalam pelaksanaan suatu proses atau aktivitas operasional.Bagi otoritas pengawas bank, penerapan manajemen risiko akan mempermudah penilaian terhadap kemungkinan kerugian yang dihadapi bank yang dapat mempengaruhi permodalan bank dan sebagai salah satu dasar penilaian dalam menetapkan strategi dan fokus pengawasan bank. Adapun tahap evolusi manajemen risiko operasional menurut Muslich (2007) dibagi menjadi empat tahap yaitu tahap identifikasi serta pengumpulan data, tahap penyusunan data, tahapa pengukuran data, dan tahap konsolidasi data untuk pengukuran perhitungan modal.

\section{Kategori penyebab risiko operasional}

Risiko operasional berdasarkan dokumen dari BCBS yang berjudul International Convergence of Capital Measurement and Capital Standards (A Revised Framework, June 2004), "Operational risk is defined as the risk of loss resulting from inadequate or failed internal processes, people and systems or from external events". Dari definisi diatas penyebab kejadian risiko operasional menurut Global Association of Risk Professional(GARP) dapat dikelompokkan ke dalam 4 kategori yaitu proses internal, Manusia, Sistem dan Kejadian eksternal.

\section{Kategori kejadian risiko operasional}

Kejadian risiko operasional berdasarkan Bank for International Settlements (BIS) di dokumen berjudul International Convergence of Capital Measurementand Capital Standards (2004), BaselCommitteeBanking Supervision (BCBS) yaitu Internal Fraud, External Fraud, Employment Practises and workplace safety, Client product and business practices, Damage to Physical Asset, Business disruption and system failure, Execution delivery and system management

\section{Pengukuran risiko operasional}

Dokumen International Convergence of Capital Measurement and Capital Standards (2004), Basel Committee Banking Supervision (BCBS) menetapkan tiga metode perhitungan modal untuk risiko operasional.Ketiga metode tersebut menggunakan berbagai indikator eksposur risiko. Indikator eksposur risiko merupakan faktor yang menunjukkan tingkat 
risiko yang dihadapi oleh bank. Semakin tinggi nilai indikator semakin tinggi risiko yang dihadapi. Ketiga model tersebut adalah : Basic indicator approach (BIA), Standardized approach (SA), Advance measurement approach.

\section{METODE PENELITIAN}

\section{Deskripsi data}

Data yang digunakan dalam penelitian ini adalah data kejadian risiko operasional bank syariah "EFG" yang disebabkan karena faktor karena lemahnya proses internal, manusia, dan eksternal selama 3 tahun terakhir (36 bulan). Pengumpulan data menggunakan metode BIA adalah mencari laba kotor (gross income) adalah pendapatan bunga bersih ditambah pendapatan operasional non-bunga tertentu lainnya bersih yang dihitung secara kumulatif dari periode awal Januari sampai dengan akhir Desember setiap tahun, atau Laba kotor $=$ Pendapatan Bunga Bersih + Pendapatan Bersih Bukan Bunga Pengumpulan data menggunakan metode AMA Data penelitian dibatasi hanya menggunakan data kerugian risiko operasional (Loss Event Database) tahunan. Data kerugian risiko operasional menggunakan data internal bank syariah "EFG" yang diperoleh dari aplikasilncident Management Data Collection (IMDC) yakni aplikasi pencatatan data kerugian yang di input oleh unit kerja Cabang dan Divisi. Selain itu melalui data kejadian risiko operasional dari Divisi Manajemen Risiko. Data kerugian risiko operasional dikelompokan berdasarkan penyebab risiko operasional yaitu proses internal, manusia dan kejadian eksternal.

\section{Jenis Penelitian}

Jenis penelitian yang dipakai adalah asosiatif, dimana tujuannya adalah untuk mengetahui mencari keterhubungan antara variabel

3. Metode Analisis Data

Metodologi yang banyak digunakan dalam Advanced Measurement Approach adalah Loss Distribution Approach menggunakan Operational Value at Risk (OpVar) dalam menghitung modal regulatori untuk mengcover risiko operasional dengan dua penetapan yaitu penetapan distribusi frekuensi kerugian dan penetapan distribusi severitas kerugian risiko operasional. Loss Distribution Approach menggunakan dasar analisa statistik atas kejadian kerugian

\section{HASIL DAN PEMBAHASAN}

\section{Analisis Deskriptif}

Pengukuran Metode Basic Indicator Approach (BIA). Untuk memperoleh nilai dari beban modal risiko operasional maka harus dicari nilai pendapatan bunga bersih 3 tahun terlebih dahulu, secara berturut turut yakni sebesar Rp1.086.983.000.000,-, Rp.1.436.966.000.000,- dan Rp. 2.025.109.000.000,-. Kemudian dilanjutkan mencari nilai total pendapatan non bunga tahun 2011, 2012 dan 2013 secara berturut turut sebesar Rp.411.118.000.000,-, Rp. 500.236.000.000,- Rp. 589.015.000.000,Selanjutnya mencari nilai total beban non bunga 3 tahun berturut turut Rp. 50.295.000.000,-, Rp. 70.201.000.000,- dan Rp. 95.891.000,-. Setelah itu dilanjutkan dengan menjumlahkan nilai pendapatan bunga bersih dengan nilai total pendapatan non bunga dikurangi nilai total beban non bunga sehingga diperoleh pendapatan kotor (gross income). Berdasarkan hasil perhitungan pendapatan bruto dari bank EFG diketahui pendapatan kotor berturut-turut Rp1.447.806.000.000,-, Rp. 1.867.001.000.000,-dan Rp. 2.518.233.000.000,-. Kemudian diperoleh ratarata pendapatan bruto selama 3 tahun sebesar Rp. 1.944.347.000.000,-, sehingga dapat diketahui beban modal risiko operasional berdasarkan metode Basic Indicator Approach (BIA) (Rp.1.944.347.000.000 x 15\%) sebesar Rp.291.652.000.000,-

\section{Analisis}

\section{a. Analisis Frequency of Loss Distribution}

Penetapan Frequency of Loss Distribution dapat dilakukan dengan Goodness of Fit pendekatan melalui pendekatan grafik dan pendekatan formal tes statistik

Dari hasil Goodnes of Fit maka frequency of loss distribution untuk Internal Proses, manusia dan kejadian external adalah distribusi Geometric.

Parameter distribusi Geometric berturut turut untuk internal proses sebesar sebesar 0.17561, untuk manusia sebesar 0.08511, untuk kejadian eksternal 0,83721.

\section{b. Analisa perhitungan Operational Value at Risk (OpVar)}

Operational Value at Risk merupakan nilai perkiraan kerugian maksimum yang dapat terjadi berdsarkan simulasi untuk confidence level tertentu.Berdasarkan tingkat keyakinan (confidence level) 99\%, maka yang akan menjadi nilai Operational Value at Risk adalah nilai ordered total pada tingkat 99\%. Berdasarkan jumlah actual loss event yang dimiliki pada penelitian sebanyak 36 data actual loss maka simulasi dilakukan sebanyak 36 kali, untuk masing-masing penyebab risiko operasional dari internal proses, manusia dan kejadian eksternal. 
Nilai OpVar dengan faktor penyebab internal Proses dapat diartikan dalam 10.000 simulasi hari kejadian dimasa yang akan datang dan berdasarkan pengalaman masa lalu yang memiliki pola distribusi geometric, maka kerugian maksimal yang dapat timbul sebesar Rp. 24,114,480,096,-, untuk faktor penyebab manusia sebesar Rp.6.010.929.367,- sedangkan untuk faktor penyebab kejadian eksternal sebesar Rp.2.161.092.909,-

\section{c. Uji back testing}

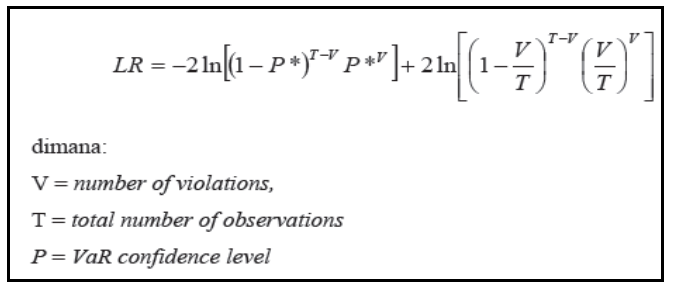

Pengujian back testing model dilakukan untuk menguji proyeksi nilai Value at Risk kerugian operasional ini dibandingkan dengan kerugian riil, untuk masing-masing penyebab kerugian risiko operasional yakni Proses Internal, Manusia dan Eksternal. Hasil uji Back testing terkait penyebab risiko operasional Proses internal nilai Likelihood ratio sebagai berikut

\begin{tabular}{|l|l|l|l|}
\hline \multicolumn{2}{|l|}{ Likelihood ratio back testing } & Chi square \\
\hline $\begin{array}{l}\text { Internal } \\
\text { proses }\end{array}$ & Manusia & $\begin{array}{l}\text { Kejaidan } \\
\text { eksternal }\end{array}$ & $\mathrm{CF}=99 \%$ \\
\hline 0.7023 & 0.7236 & 0.7749 & 6.634896601 \\
\hline Not rejected & Not rejected & Not rejected & \\
\hline
\end{tabular}

\section{PEMBAHASAN HASIL PENELITIAN}

Beban Modal Risiko Operasional metoda BIA

\begin{tabular}{|c|c|c|c|c|}
\hline \multicolumn{5}{|c|}{ Dalam Jutaan } \\
\hline A & $\begin{array}{l}\text { Pendapatan } \\
\text { Bruto }\end{array}$ & $2,518,233$ & $1,867,001$ & $1,447,806$ \\
\hline $\mathrm{B}$ & $\begin{array}{l}\text { Rata-rata } \\
\text { Pendapatan } \\
\text { Brutto }\end{array}$ & & & $1,944,347$ \\
\hline $\mathrm{C}$ & $\begin{array}{l}\text { Beban } \\
\text { Modal utk } \\
\text { Resiko } \\
\text { Operasional } \\
\text { (15\% X B) }\end{array}$ & & & 291,652 \\
\hline $\mathrm{D}$ & $\begin{array}{l}\text { ATMR utk } \\
\text { Resiko } \\
\text { Operasional }\end{array}$ & & & $3,645,650$ \\
\hline
\end{tabular}

\begin{tabular}{|l|l|l|l|l|}
\hline & $(12,5 \times \mathrm{X})$ & & & \\
\hline
\end{tabular}

Beban Modal Risiko Operasional Berdasarkan BIA sebesar Rp.291.652.000.000,-

\section{Beban Modal Risiko Operasional metoda AMA}

\begin{tabular}{|c|c|c|c|}
\hline \multicolumn{3}{|c|}{ Penyebab Risiko Operasional } & OpVaR \\
\hline $\begin{array}{c}\text { Internal } \\
\text { Process }\end{array}$ & Manusia & Eksternal & $\begin{array}{c}\text { (Confident Level } \\
\mathbf{9 9 \%})\end{array}$ \\
\hline $24,114,480,096$ & $6,010,929,367,-$ & $2,161,092,909,-$ & $32,286,502,372.00$ \\
\hline
\end{tabular}

Metode penelitian ini menggunakan simulasi monte carlo sebanyak 10.000 kali dengan menggunakan Penyebab risiko operasional yang digunakan dalam penelitian ini adalah data kerugian disebabkan Proses Internal (internal process),manusia (people), dankejadian eksternal (external event),

penelitian ini juga melakukan perbandingan perhitungan beban modal (capital charge) risiko operasional antara metode Basic Indicator Approach (BIA) dengan metode Advance Measurement Approach (AMA). Dari hasil perbandingan tersebut maka dapat diambil kesimpulan kebutuhan modal risiko operasional menggunakan metode Advanced Measurement Approach (AMA) yaitu sebesar Rp. 32,286,502,372,- lebih kecil dibandingkan dengan kebutuhan menggunakan metode Basic Indicator Approach (BIA) sebesar Rp.291.652.000.000,Makapengukuran bebanmodal risiko operasional menggunakan metode Advanced Measurement Approach (AMA) adalah yang paling tepat yang diperlukan untuk mengcover risiko operasional yang terjadi di Bank EFG.

\section{PENUTUP}

\section{Kesimpulan}

Pengukuran beban modal risiko operasional menggunakan metode Basic Indicator Approach (BIA) pada Bank EFG diperoleh angka sebesar Rp.291.652.000.000,-. Metoda BIA mengukur kebutuhan modal risiko operasional hanya berdasarkan pendapatan kotor dari bank, sehingga tidak sensitif terhadap risiko operasional. Sehingga dapat dikatakan pendekatan BIA terbatas (Idroes, 2008) karena hal berikut :

a) BIA mengasumsikan tingkat risiko operasional yang dijalankan sebuah bank secara langsung proposional terhadap ukuran pendapatan kotor. 
b) BIA memperlakukan bisnis bank yang High Margin - Low Volume sama dengan Low Margin - High Volume, meskipun profile risiko usaha bank tersebut berbeda.

c) Tidak ada penilaian terhadap jenis kejadian (events) risiko operasional bank, frekwensi,pengawasan internal bank dimana bank tersebut beroperasi.

d) Penggunaan pendapatan bruto sebagai suatu indikator eksposur risiko operasional dapat dikategorikan sangat sederhana.

Dari hasil seluruh tahapan maka beban modal risiko operasional mengunakan metode Advanced Measurement Approach sebesar Rp 24,114,480,096,-Rp 6,010,929,367,-+ Rp 2,161,092,909,-- total sebesar Rp. 32,286,502,372,--.

Hasil perbandingan beban modal risiko operasional antara metode BIA dengan AMA dapat disimpulkan, beban modal dengan metode AMA lebih kecil yaitu sebesar Rp. 32,286,502,372,-.. dibandingkan dengan metode BIA sebesar Rp.291.652.000.000

\section{Saran}

a) Dari ke tiga penyebab risiko operasional, dari hasil penelitian di simpulkan Proses Internal memiliki potensi penyebab tertinggi dibandingkan manusia dan ekternal. Risiko operasional yang disebabkan proses internal didefinisikan sebagai risiko yang terkait dengan kegagalan proses atau prosedur yang terdapat pada suatu bank. Dalam pelaksanaan kegiatan operasional sehari-hari, staf akan melaksanakan kegiatan yang telah ditetapkan sebelumnya. Mitigasi risiko operasional yang disebabkan oleh proses internal sebagai penyebab risiko operasional tertinggi maka perlu diantisipaasi segera melalui pengendalian kepatuhan terhadap sistem dan prosedur, optimalisasi fungsi supervisory dari atasan ke sub ordinat, serta fungsi dual control terhadap kebenaran pelaporan ke regulator (check and re check).

b) Metode Advanced Measurement Approach (AMA) sangat mengandalkan akurasi data kerugian internal. Beberapa saran yang berkaitan dengan penggunaan data kerugian internal (Internal Loss Data), sebagai berikut :
1. Untuk dapat menggunakan Advanced Measurement Approach, bank harus memiliki sistem pengukuran risiko operasional yang terintegrasi dengan proses manajemen risiko harian dari bank

2. Bank harus melakukan proses mengunpulkan, menyimpan, memelihara dan membuat laporan tentang informasi historis kerugian internal risiko operasional. Database tersebut dipakai untuk memprediksi potensi kerugian dimasa yang akan datang menggunakan pengalaman bank dimasa lalu.

c) Terdapat beberapa masalah inheren dalam penggunaan internal data seperti kualitas dan dan ketepatan data, karena akan berakibat pada keakuratan perhitungan kebutuhan modal risiko operasional pada metode AMA

d) Perlu dikembangkan lebih lanjut penelitian terhadap pengukuran beban modal risiko operasional yang disebabkan factor eksternal dimana kejadian tersebut jarang terjadi dan jika terjadi mempunyai dampak nilai kerugian yang sangat besar (Low Frequency and High Impact). Pengukuran tersebut dapat dilakukan dengan metode Extreme Value Theory (EVT), yang digunakan untuk mengestimasi potensi besarnya kerugian yang melebihi VaR (Value at Risk).

\section{REFERENSI}

A Suhartono, W Jati, D Sunarsi. (2019). Pengaruh Earning Per Share Dan Return On Asset Terhadap Harga Saham Pada PT. Bank Negara Indonesia Tbk Periode 2009-2018. Jurnal Manajemen, Bisnis dan Organisasi (JUMBO) 3 (3), 182-194.

Bank for International Settlement, 2004, International Convergence of Capital Measurement and Capital Standards (A Revised Framework), BCBS.

Bank Indonesia, 2003, Pedoman Penerapan Manajemen Risiko Bagi Bank Umum, Direktorat Penelitian dan 
Pengaturan Perbankan Bank Indonesia.

Bank Indonesia, 2005,Kewajiban Penyediaan Modal Minimum bagi Bank Umum

Bank Indonesia, 2011, Penerapan Manajemen Risiko Bagi Bank Umum Syariah dan Unit Usaha Syariah, Direktorat Penelitian dan Pengaturan Perbankan Bank Indonesia.

Bessis, Joel, 2002, Risk Management in Banking, John Wiley \& Son, Ltd

Bratanovic, Greuning, 2009, Analisis Risiko Perbankan, Salemba Empat

Chernobai, Rachev, Fabozzi, 2007, Operational Risk, A Guide to Basel II Capital Requirement, Models, and Analysis, John Willey \& Sons, Inc.

D Sunarsi. (2014). Pengaruh Gaya Kepemimpinan, Motivasi dan Disiplin Kerja Terhadap Kinerja Pendidik. Universitas Pamulang

Ghozali, Imam, 2007, Manajemen Risiko Perbankan, Badan Penerbit Universitas Diponegoro.

Global Association of Risk Professionals, 2005, Indonesia Certificate In Banking Risk and Regulation, Workbook Tingkat 1, Badan Setifikasi Manajemen Risiko

Gumilar, I., Sunarsi, D. (2020). Comparison of financial performance in banking with high car and low car (Study of banks approved in the kompas 100 index for the period 2013-2017). International Journal of Psychosocial Rehabilitation. Volume 24 - Issue 7

Idroes, N Ferry, 2008, Manajemen Risiko Perbankan, Rajawali Pers

Jobst, Andreas A, 2007, It's all in the data - consistent operational risk measurement and regulation, Journal of Financial Regulation andComplianceVol. 15 No. 4, 2007, Emerald Group Publishing Limited.

Maddinsyah, A., Sunarsi, D., Hermawati, R., Pranoto. (2020). Analysis of location selection effect on the user decision that influcence the success of the service business of micro, small and medium enterprise (MSME) in bandung timur region. International Journal of Advanced Science and Technology. Vol. 29 No. 06

Miller, Michael B, 2012, Mathematics and Statistics for Financial Risk Management, John Willey \& Sons, Inc.

Muslich, Muhammad, 2007, Manajemen Risiko Operasional, Bumi Aksara.

Romadhona, Novilia, 2006, Pengukuran Risiko Operasional Dengan Metode Aggregating Value At Risk (Kasus Pada Bank DEF), MMUI

Supardi, 2013, Aplikasi Statistika Dalam Penelitian, Change Publication.

Widarjono, Agus, (2013), Ekonometrika, Pengantar dan Aplikasinya, UPP STIM YKPN

www.emeraldinsight.com

Yang Melaksanakan Kegiatan Usaha Berdasarkan Prinsip Syariah, Direktorat Penelitian dan Pengaturan Perbankan Bank Indonesia. 